\title{
Bison Versus Cattle: Are They Ecologically Synonymous?
}

\author{
Michel T. Kobl, ${ }^{1}$ Paul R. Krausman, ${ }^{2}$ Kyran Kunkel, ${ }^{3}$ and David M. Williams ${ }^{4}$ \\ Authors are ${ }^{1}$ Boone and Crockett Fellow, Boone and Crockett Program in Wildlife Conservation, University of Montana, Missoula, MT 59812, USA; \\ ${ }^{2}$ Boone and Crockett Professor, Boone and Crockett Program in Wildlife Conservation, University of Montana, Missoula, MT 59812, USA; ${ }^{3}$ World \\ Wildlife Fund-Northern Great Plains Program, Bozeman, MT 59715, USA; and ${ }^{4}$ Assistant Professor, Quantitative Wildlife Laboratory, Department of \\ Fisheries and Wildife, Michigan State University, East Lansing, MI 48824, USA.
}

\begin{abstract}
Historically, the plains bison (Bison bison Linnaeus) was the most numerous and influential grazer on the Great Plains. Today 500000 bison occupy North America among more than 100000000 cattle. In an attempt to restore their historical ecological role, bison are translocated onto landscapes previously manipulated for cattle use through water and fence development. We hypothesized that bison would use these landscapes similarly to cattle, thus maintaining homogenous grazing and reducing the restoration potential of bison at a landscape scale. We quantified differences between bison populations at different locations and spatial scales (American Prairie Reserve, Malta, Montana, USA, and Grasslands National Park, Val Marie, Saskatchewan, Canada, 2010-2011) and bison and cattle at similar locations and spatial scales using behavioral observations, movement analyses, and resource selection functions. Bison and cattle differed in all behaviors (grazing, standing, bedded, moving, other); however, landscape attributes resulted in behavior differences within species. Cattle spent a higher proportion of time grazing $(45-49 \%)$ than bison (26-28\%) and increased time at water. Bison moved at a 50-99\% faster rate than cattle, and first passage time movement analyses identified selection of bison foraging patches (11690 ha) larger than cattle foraging patches (48-615 ha). Similar to cattle, bison avoided most vegetation communities in relation to riparian communities and selected areas closer to water. Cattle selected for high plant biomass, whereas bison selected for intermediate plant biomass. This study has implications when bison and cattle are used to meet prairie restoration objectives. For bison, large landscapes that include variation in topography and vegetation communities are required. Furthermore, limiting manmade water sources may facilitate bison grazing patterns that more closely approximate historical bison use. For livestock, reduced movement and increased time spent grazing encourage grazing practices that increase heterogeneous grazing at a pasture scale.
\end{abstract}

Key Words: behavior, first-passage time, grazing, heterogeneity, resource selection, water

\section{INTRODUCTION}

The near extinction and subsequent recovery of plains bison (Bison bison Linnaeus) throughout North America was the first and greatest conservation success in North America (Sanderson et al. 2008). Today $\sim 500000$ bison occupy North America because of the cooperation of private individuals, nonprofit organizations, and the federal governments of the United States, Canada, and Mexico. Despite the numerical recovery of the species, recent questions have surfaced regarding the ecological success of these efforts because fewer than 21000 plains bison are managed as conservation herds (i.e., not for commercial use; $n=62)$. Thirteen percent $(n=8)$ of conservation herds are outside of their historical range, 92\% $(n=57)$

Research was funded by the Alfred P. Sloan Foundation, American Prairie Reserve, Boone and Crockett Wildlife Conservation Program at the University of Montana, M. J. Murdock Charitable Trust, Montana Institute on Ecosystems by the National Science Foundation EPSCoR program grant EPS-1101342, Parks CanadaGrasslands National Park, University of Montana, Wildlife Conservation Society Research Fellowship Program, and the World Wildlife Fund-Northern Great Plains Program.

At the time of research, Kohl was a Boone and Crockett Fellow, Boone and Crockett Wildlife Conservation Program, University of Montana, Missoula, MT 59812, USA.

Correspondence: Michel Kohl, Dept of Wildland Resources, Utah State University, Logan, UT, 84321, USA. Email: michel.kohl@aggiemail.usu.edu

Manuscript received 28 August 2012; manuscript accepted 13 August 2013.

(c) 2013 The Society for Range Management have fewer than 1000 individuals, and only $8 \%(n=5)$ are managed on areas of more than $2000 \mathrm{~km}^{2}$ (Gates et al. 2010). In comparison, more than $95 \%$ of bison are in commercial production and are subjected to animal husbandry practices (e.g., altered sex:age ratios, unnatural growth performance, reduced mate competition), which may result in irreversible changes to morphology, physiology, and behaviors (Freese et al. 2007) that alter their ecological influence on the landscape. The collective effect of ecological alterations and issues such as disease (Aune and Gates 2010) and domestic cattle gene introgression (Halbert and Derr 2007) can prohibit the mixing of commercial and conservation herds because of different management and conservation goals. As a result, many conservation groups and state and federal agencies are questioning the ecological significance of replacing historic bison populations with domestic cattle at a landscape scale.

Historically, bison were the dominant grazer throughout the Great Plains, affecting vegetation communities through grazing, physical disturbance, nutrient cycling, and seed dispersal (McHugh 1958; Knapp et al. 1999). These activities contributed to grassland heterogeneity that supported many prairie obligate species (e.g., grassland songbirds) in the tall, mixed, and short grass prairie (Fuhlendorf et al. 2006; Powell 2006; Gates et al. 2010). Following the reduction of the bison herds, bison were replaced by domestic cattle, and a significant shift occurred, resulting in overgrazing and then rotational grazing regimes. Contemporary range management practices are 
designed to maximize livestock production through crossfencing and uniformly distributed stock reservoirs, effectively rescaling the grazing process across the landscape in a homogenous fashion (Fuhlendorf and Engle 2001; Derner et al. 2009).

Today livestock numbers on rangelands in the United States and Canada are two times higher than historical bison estimates, ${ }^{1}$ yet there are few studies comparing the ecological similarities between introduced livestock and bison, particularly when managed as wild populations on large, complex landscapes (Fuhlendorf et al. 2010). Bison and cattle demonstrate fundamental ecological differences in habitat use (van Vuren 1983; Allred et al. 2011), forage use (Peden et al. 1974; Plumb and Dodd 1993; Towne et al. 2005), and behavior (Plumb and Dodd 1993). In addition, water requirements have been identified as a major difference between the species as cattle spend more time near water resources and riparian areas than bison (van Vuren 1983; Fuhlendorf et al. 2010). In particular, bison employ distinct travel patterns that include travel from general use areas (e.g., feeding, bedding) to watering areas where they spend minimal time and then return to general use areas (McHugh 1958; van Vuren 1979). However, only Allred et al. (2011) have explicitly tested for cattle selection and bison avoidance of riparian areas and water sources at a large spatial scale.

Data are available regarding the ecological differences between bison and cattle; however, direct comparisons between bison and cattle are difficult because of varying management practices (e.g., pasture size, stocking densities, management priorities, cattle breed) and confounding environmental factors (Plumb and Dodd 1993; Towne et al. 2005; Fuhlendorf et al. 2010). Fuhlendorf et al. (2010) reported nine studies that compared bison and cattle with an ecological focus, only two of which attempted to control for confounding effects. Recent work on the Tallgrass Prairie Reserve was the third study to control for confounding effects and the first to occur on pasture units over 300 ha (Allred et al. 2011).

Bison translocation efforts are occurring in the Northern Great Plains in areas previously manipulated for livestock (i.e., water development and fence construction). Because these translocation efforts are implemented beside domestic livestock operations, we were provided opportunities for side-by-side comparisons of bison and cattle. Furthermore, with multiple bison populations within the region, we were able to compare pasture attributes used by bison across differing vegetation communities and spatial scales. Thus, our objectives were to compare the behavior, movement, and resource use of bison and cattle on large pasture units $(>1000 \mathrm{ha})$ within the Northern Great Plains in an effort to make inferences regarding potential impacts on landscape heterogeneity. For this study, landscape hetero- and homogeneity refers to vegetation structure and composition at spatial scales of more than $1000 \mathrm{~km}^{2}$. Pasture attributes refer to topographic characteristics, vegetation communities, and management practices. We hypothesized that pasture attributes would influence the behaviors (e.g., standing, bedded, grazing, movement, and resource use) of bison and cattle. As such, we predicted bison and cattle in units with similar pasture attributes would

\footnotetext{
Fig. S1, available at http://dx.doi.org/10.2111/REM-D-12-00113.s1)
}

demonstrate comparable behaviors reported in previous studies of smaller pasture units. We also predicted bison would differ in their ecological behaviors (e.g., movement, water use) when under different management structures, including pasture size and water density.

\section{METHODS}

\section{Study Area}

We compared bison and cattle in two study areas within the northwestern glaciated plain ecoregion (Forrest et al. 2004) of north-central Montana and southwestern Saskatchewan, Canada, in 2010 and 2011 (Fig. 1). In north-central Montana, we compared bison on the American Prairie Reserve (APR [67\% public land]) and cattle on the Barnard Ranch (BR [65\% public land]) and Weiderrick Ranch (WR [100\% public land]). The APR (lat $47^{\circ} 45^{\prime} 48^{\prime \prime} \mathrm{N}$, long $107^{\circ} 41^{\prime} 43^{\prime \prime} \mathrm{W}$ ) is located $74 \mathrm{~km}$ south of Malta, Montana, and is adjoined on the east by BR (lat $47^{\circ} 43^{\prime} 00^{\prime \prime} \mathrm{N}$, long $107^{\circ} 38^{\prime} 00^{\prime \prime} \mathrm{W}$ ) and west by WR (lat $47^{\circ} 44^{\prime} 11^{\prime \prime} \mathrm{N}$, long $\left.107^{\circ} 51^{\prime} 28^{\prime \prime} \mathrm{W}\right)$. To compare bison across spatial scales, vegetation communities, and water availability, a second bison site was selected $150 \mathrm{~km}$ north in Grasslands National Park (GNP [Val Marie, Saskatchewan, Canada \{lat $49^{\circ} 09^{\prime} 40^{\prime \prime} \mathrm{N}$, long $\left.\left.\left.107^{\circ} 32^{\prime} 49^{\prime \prime} \mathrm{W}\right\}\right]\right)$.

Dominant plant species on APR, BR, and WR are representative of a sagebrush steppe system that includes blue grama (Bouteloua gracilis Griffiths), needlegrass (Stipa spp. Beauv), crested wheatgrass (Agropyron cristatum Gaertn), silver sagebrush (Artemisia cana Pursch), and Wyoming big sagebrush (Artemisia tridentata Nutt). Sedges (Carex spp.), cacti, and forb species are also common in the area. Dominant plant species in GNP are representative of the mixed-grass prairie ecosystems and include blue grama, needlegrass, western wheatgrass (Pascopyrum smithii Á Löve), and silver sagebrush.

Large ungulates on all sites include mule deer (Odocoileus hemionus Rafinesque), white-tail deer (O. virginianus Zimmermann), and pronghorn (Antilocapra americana Ord). Elk (Cervus elaphus Linnaeus) are common on all sites except GNP. Black-tailed prairie dogs (Cynomys ludovicianus Ord) and coyotes (Canis latrans Say) are common in all areas. Greater sage grouse (Centrocercus urophasianus Bonaparte), Baird's sparrows (Ammodramus bairdii Audubon), and mountain plover (Charadrius montanus Townsend) are grassland bird species of conservation concern found throughout the region.

The APR, BR, and WR lie in a semiarid region consisting of upland flats intersected by coulees and ephemeral streams flowing toward the Missouri River. Yearly precipitation ranges from 25.4-27.9 cm; however, 2010 and 2011 were 1.5-2.0 greater than the annual average $(45.6$ and $57.1 \mathrm{~cm}$, respectively). Mean annual temperature is $6.5^{\circ} \mathrm{C}$ and ranges from $-8.4^{\circ} \mathrm{C}$ in January to $20.8^{\circ} \mathrm{C}$ in July. Elevation ranges from 700 to 825 $\mathrm{m}$. Soil primarily contains heavy clay loams with moderate amounts of salt resulting in high impermeability by water. Thus, most water developments remain full throughout the year.

The GNP also lies in a semiarid region and consists of similar topographic features as listed above. The Frenchman River 

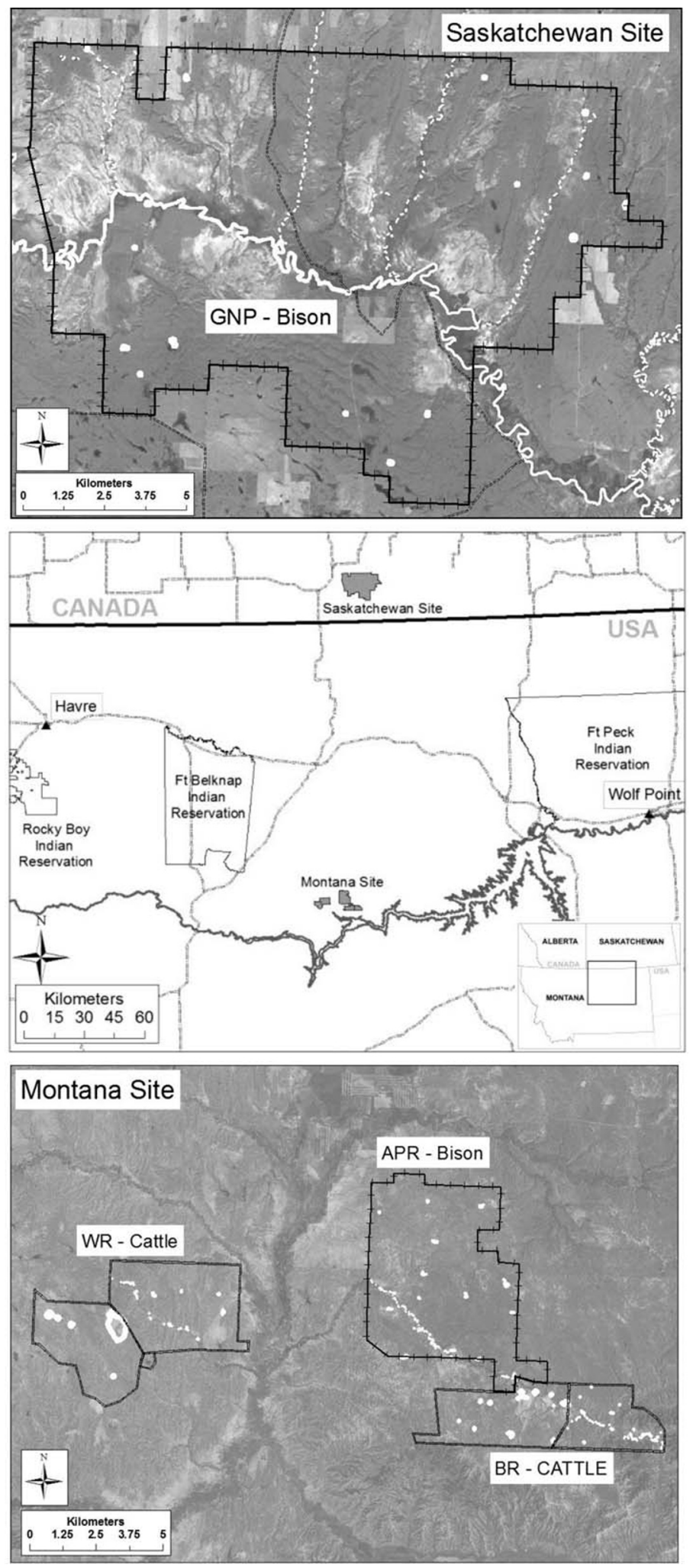

Figure 1. Location of bison and cattle study sites. Bison herds were located at American Prairie Reserve (APR; diamond) and Grasslands National Park (GNP; star). Two cattle herds are located in pastures adjacent to APR bison herd. White identifies man-made stock reservoirs and remnant pools within ephemeral streams. Dashed line identifies main ecotour route through GNP. Sites at APR are located $74 \mathrm{~km}$ south of Malta, MT, USA, and GNP is located $20 \mathrm{~km}$ southeast of Val Marie, SK, Canada. runs through the southern section of the park with consistent, regulated flow throughout the year. Annual precipitation ranges from 30 to $33 \mathrm{~cm}$; however, 2010 and 2011 were 1.42.0 times greater than average ( 46.5 and $53.1 \mathrm{~cm}$, respectively). Mean annual temperature is $3.4^{\circ} \mathrm{C}$ and ranges from $-13.4^{\circ} \mathrm{C}$ in January to $18.8^{\circ} \mathrm{C}$ in July. Elevation ranges from 750 to $900 \mathrm{~m}$.

Bison on APR ( $n=147$ in and 215 in 2010 and 2011, respectively) were contained within a 3555 ha electrified pasture unit from 1 May through 31 October of each year (Fig. 1). The pasture contains 15 manmade reservoirs and an ephemeral stream that maintained small remnant pools during the study. Reynolds Hill Road passes through the eastern section of the APR, receiving low to moderate levels $(\sim 30$ vehicles $\cdot \mathrm{d}^{-1}$ ) of use throughout the summer with heavier use $\left(\sim 250\right.$ vehicles $\left.\cdot \mathrm{d}^{-1}\right)$ during hunting season (1 September-25 November). Bison on GNP ( $n=147$ and 195 in 2010 and 2011, respectively) were contained within an 18153 ha pasture unit containing 26 reservoirs (Fig. 1); however, bison typically used only the northeast portion of the park during summer $(\sim 4200$ ha). This summer area contained five manmade reservoirs (three of which were permanent throughout summer), one large depression, and three ephemeral channels that contained remnant pools during the study. In addition to reservoirs, the Frenchman River provides water throughout the year, except when frozen. The main ecotour road passes through the center of the park $\left(\sim 6000\right.$ visitors $\left.\cdot \mathrm{yr}^{-1}\right)$ from north to south and receives low to moderate levels of use throughout the summer, but recreational use is rare in the core summer range.

The WR grazed 100 cow/calf pairs (red and black Angus) from 1 July to 15 October on 2 rotational pastures (1090 and $1408 \mathrm{ha}$ ), that contained 5 to 7 reservoirs per pasture (Fig. 1). The BR grazed $\sim 140$ cow/calf pairs (Hereford and red Angus) on two rotational pastures (777 and 1000 ha) that contained 6-8 reservoirs per pasture. The west BR pasture was bisected by Reynolds Hill Road. Stocking density was similar across APR and WR cattle pasture units but differed from BR pasture units (Table 1).

\section{GPS Data Collection}

We deployed Global Positioning System (GPS) radiocollars (Lotek 3300, Lotek 4400, Lotek Wireless Fish and Wildlife Monitoring, Newmarket, Ontario, Canada and NSG-LD2, North Star Science and Technology, LLC, King George, Virginia, USA) on adult female bison and cattle. ${ }^{2}$ Bison were immobilized (A3080 and Xylazine; reversed with Naltrexone, or a mixture of Butorphanol-Azaperone-Medetomidine $[$ BAM]; reversed with Naltrexone, Atipamezole and Tolazine, K. Kunkel, American Prairie Reserve, personal communication) by air-powered darts (Pneu-Dart, Williamsport, PA) fired from the ground. Cattle were physically restrained in a squeeze chute. Sixteen animals were instrumented in the study ( $n=2$ on APR, $n=4$ on GNP, $n=5$ on BR, $n=5$ on WR), of which five individuals remained collared throughout the duration of the study ( $n=2$ on APR, $n=3$ on GNP). Collars were scheduled to obtain locations every 1,2 , or $3 \mathrm{hr}$ from collar deployment (1 June-9 July) till 31 August (or until collar failure) in 2010 and 2011 . $^{3}$ The GPS locations were

\footnotetext{
${ }^{2}$ Fig. S2, available at http://dx.doi.org/10.2111/REM-D-12-00113.s2

${ }^{3}$ Table S1, available at http://dx.doi.org/10.2111/REM-D-12-00113.s3
} 
Table 1. Description of grazing pastures and stocking densities for animals owned by American Prairie Reserve (APR), Parks Canada (PC), Weiderrick Ranch (WR), and Barnard Ranch (BR). Analysis was performed on annual bison range (Park) and within summer home range (NE Corner) in Grasslands National Park (GNP). The GNP is located $20 \mathrm{~km}$ southeast of Val Marie, SK, Canada, and other sites are located $74 \mathrm{~km}$ south of Malta, Montana, USA.

\begin{tabular}{|c|c|c|c|c|}
\hline Species & Owner & Pasture name & Year & AUM/ha \\
\hline \multirow[t]{6}{*}{ Bison } & APR & APR & 2010 & 0.25 \\
\hline & & & 2011 & 0.18 \\
\hline & $P C$ & GNP_Park Wide & 2010 & 0.11 \\
\hline & & & 2011 & 0.14 \\
\hline & & GNP_NE Corner & 2010 & 0.14 \\
\hline & & & 2011 & 0.18 \\
\hline \multirow[t]{6}{*}{ Cattle } & WR & North & 2010 & 0.14 \\
\hline & & & 2011 & 0.09 \\
\hline & & West & 2011 & 0.16 \\
\hline & BR & East & 2010 & 0.36 \\
\hline & & & 2011 & 0.49 \\
\hline & & West & 2011 & 0.39 \\
\hline
\end{tabular}

censored from analysis when APR bison moved outside of the designated pasture unit. This research was approved by the University of Montana Animal Care and Use Board (Animal Use Protocol No. 014-10PKWB) and Parks Canada (Permit No. GRA-2010-5415).

\section{Landscape Variables}

Abiotic variables (e.g., aspect, slope, and elevation) were developed from the $30 \times 30 \mathrm{~m}$ Montana Digital Elevation Model and $15 \times 15 \mathrm{~m}$ Canadian Digital Elevation Model. Biotic variables included vegetation community and $250 \times 250$ m Normalized Difference Vegetation Index data (NDVI [Moderate Resolution Imagine Spectroradiometer \{Huete et al. 2002\}]). Vegetation classifications on GNP were based on field work completed by ground sampling (R. Sissons, GNP, unpublished data). Landcover type was classified on APR, BR, and WR using remotely sensed data and was designed to allow for comparison between vegetation communities on GNP. We delineated 10 vegetation communities (eroded, upland grassland, disturbed, sloped grassland, riparian, valley grassland, treed, unclassified, sage-brush, and water bodies). ${ }^{4}$ We used a dynamic measure of vegetation productivity by estimating primary productivity from midmonth NDVI estimates (Tucker and Sellers 1986). We analyzed anthropogenic variables using Euclidean distance estimates $(\mathrm{km})$ for fence, water, and roads. We located permanent water sources using BLM (Malta Field Office, Malta, MT, USA) and Parks Canada (GNP Headquarters, Val Marie, Canada) topographic maps. We inspected water developments monthly to confirm water availability throughout summer. Additional water sources (e.g., hardpans, rainfall, drainages) are ephemeral pools ( $<1 \mathrm{wk})$; thus we assumed they were homogenous throughout the pasture units

\footnotetext{
${ }^{4}$ Table S2, available at http://dx.doi.org/10.2111/REM-D-12-00113.s4
}

and did not influence overall movement patterns of bison and cattle relative to permanent water sources.

\section{Behavior}

We conducted behavior observations of bison and cattle near semipermanent $(<3 \mathrm{mo})$ to permanent water sources to quantify the use of water by both species, and thus relate resource selection (see below) to water requirements. The distinct differences in use of watering areas by bison and cattle (van Vuren 1983; Fuhlendorf et al. 2010) allowed for inferences on the impact of variable water densities on landscape use by bison and the overall requirement of water by bison relative to cattle. Thus, we predicted time spent watering would differ between species (i.e., cattle $>$ bison). We also predicted differences in time spent watering across bison sites (i.e., GNP>APR) due to GNP's decreased water availability in the northeast corner of the park, thus imitating a more historical water density.

Opportunistic behavioral observations were also recorded when groups of individuals were $\geq 25 \mathrm{~m}$ from water (25-1027 $\mathrm{m})$. We assumed that at distances over $25 \mathrm{~m}$, animals had not watered recently, and thus would make directed movements when watering was required. Observations $(\leq 4 \mathrm{hr})$ occurred during daylight hours twice per day for one week per month per study group from 22 May-23 August 2010 and 2011. We were unable to collect observation data and watering events for $1.5 \mathrm{mo}$ on the $\mathrm{BR}$ in 2010 due to the grazing rotation schedule and access was limited to WR in 2010 and 2011 due to weather conditions. This resulted in 87 behavioral observations ( $n=34$ on APR, $n=29$ on GNP, $n=18$ on BR, $n=6$ on WR) spanning $155.3 \mathrm{hr}$ and 544 watering events (i.e., the start of an adult animal drinking water), across all study areas $(n=200$ on APR, $n=185$ on GNP, $n=119$ on BR, $n=40$ on WR). Prewatering behavior of mixed groups (female, calf, and subadult males) was determined using instantaneous scan sampling (Altmann 1974) from distances over 100 m (Komers et al. 1992) and pooled across individuals within the sampling unit. A sampling unit consisted of a group of more than 2 animals separated from other groups by more than $100 \mathrm{~m}$ (range $=2-224$; median $=38$ [Fortin et al. 2003]) with multiple groups being observed concurrently if visible. Prior to watering events, behavior (grazing, standing, bedded, moving, other) of all individuals was recorded at $15 \mathrm{~min}$ intervals (Plumb and Dodd 1993). During the observation periods, individuals were also observed continuously for instances of watering events. When an individual animal began watering, the observation period (instantaneous scan samples) for all individuals ceased, and weather data (temperature, cloud cover, wind speed) and time spent at water (i.e., time in minutes from initial drinking activity to time when animal was more than one body length from water source) for each watering individual was recorded.

We calculated proportional differences in ecologically significant behaviors (i.e. moving, grazing). We used a $\chi^{2}$ test to quantify whether behaviors differed among and within species. We used ANOVA to compare time spent at water between species and study locations. Lastly, a multiple analysis of variance (MANOVA) was used to calculate the influence of temperature on time spent at water. Statistical 
analyses were conducted using the Rcmdr package in $\mathrm{R} 2.15 .1$ (Fox 2005).

\section{Movement}

We predicted bison movement rates (MR), calculated from GPS data as distance $(d)$ in meters (step length) divided by time $(t)$ in seconds (fix interval), would be larger than those of cattle on pasture units of similar attributes due to increased resource (i.e., water) requirements by cattle. This would be expected if cattle were unable to travel large distances from water when physiologically constrained by higher summer temperatures and, thus, resulting in circular movements within a given radius of a watering source. In contrast, we expected bison to make linear movements away from water sources, which would result in greater movement rates. We also predicted bison on APR would demonstrate slower MR than bison on GNP due to reduced pasture units (i.e., fence construction). This would be expected if long-distance movements were inhibited by fence construction, thus decreasing the total distance traveled relative to a fix-interval. Movement rates had a non-normal distribution; thus we used a negative binomial regression to test this hypothesis. Analyses were performed in R 2.15.1 using the MASS package (Venables and Ripley 2002).

We used the first passage time (FPT) analyses to measure the search effort along a pathway (Fauchald and Tveraa 2003) to identify the spatiotemporal scale of biologically relevant movements (Turchin 1998; Morales et al. 2005). Specifically, FPT incorporates step length, turning angles, and tortuosity (Fauchald and Tveraa 2003) to estimate the spatial scale at which the consumer perceives a resource. Variance in FPT, calculated by the time it takes an animal to travel across a circle of a specified radius (Fauchald and Tveraa 2003), allows ecologists to distinguish area-restricted search behaviors from movement behaviors between patches.

FPT analyses were conducted in the adehabitatLT package of R 2.15.1 (Calenge 2006). Circles of radii between 50 and $15000 \mathrm{~m}$, increasing at $25 \mathrm{~m}$ increments, were applied to each GPS location along an individual movement path for bison and cattle. Location data were used from the focal sampling period (June-August 2010 and 2011) except for APR bison in 2011. The omission of 2011 data for APR bison was due to temporary bison movements outside of the designated pasture unit, which necessitated data censoring and resulted in an inadequate sample size for FPT analysis. For each GPS location along an individual movement path, we calculated the time spent moving along the path within a circle of a given radius. Where those circles intersected the movement path, we determined passage time of the resulting segment assuming constant rates of travel along interlocation steps. First passage times were not calculated in instances of missed locations which created breaks along the path (Williams et al. 2012). We evaluated the variation in passage time along each movement path using circles with radii ranging from 50 to $15000 \mathrm{~m}$ at $25 \mathrm{~m}$ increments. Variation in FPT at each scale (circle radius) indicates the degree that movements are aggregated along the path. Because variation in FPT is expected to increase with increasing circle radii, variance in FPT was divided by the area of the circle (Frair et al. 2005;
Williams et al. 2012) as a function of scale (circle radii), thus providing an indicator of the landscape scales to which individuals are responding for the summers of 2010 and 2011.

\section{Resource Selection}

We used a resource selection function (RSF) framework to compare resource use of bison and cattle during summer (1 June-31 August; Manly et al. 2002). Our specified covariates were vegetation community, water availability, and additional abiotic (elevation, aspect, slope), biotic (NDVI), and anthropogenic covariates (distance to roads, distance to fence) identified in previous bison and cattle resource selection studies. Because RSFs assume independence among observations (Hosmer and Lemeshow 2000), we used generalized linear mixed-models (GLMM) with a random-intercept for individual to allow for interpretation of selection among different populations and species (Hebblewhite et al. 2008; Bolker et al. 2009), thus accounting for temporal and spatial autocorrelation among individuals and groups (Breslow and Clayton 1993) and correcting for unbalanced number of locations among individuals (Bennington and Thayne 1994). Furthermore, data were pooled by month for each animal (i.e., Animal1_June2010, Animal2_June2010, Animal1_ July2010, etc.) to provide a population estimate across the summer months while taking into account changing availability in our dynamic measure of vegetation productivity, NDVI.

We estimated RSFs at the third order scale (Johnson 1980) on APR, GNP, and cattle ranches. On APR and cattle pastures, we randomly sampled monthly availability $(n=1000)$ across individual months within a given pasture for bison and cattle. In GNP we randomly sampled monthly availability $(n=1000)$ within a $95 \%$ fixed kernel monthly home range (third order) using Geospatial Modeling Environment 6.0 (Beyer 2012). In GNP, we also estimated RSFs at a constrained second order scale (i.e., pasture unit) by randomly sampling monthly availability $(n=2000)$ across the entire park to understand whether resource selection differed across spatial scales in GNP. We define this as constrained second order resource selection because the area is used throughout the year; however, we cannot explicitly state whether this area would encompass the bison's annual population range if no peripheral fence existed. A GLMM was estimated using the lme4 package (Bates et al. 2011) for R 2.15.1 and included our covariates (described above). For categorical covariates, we selected riparian communities as the reference category for vegetation due to previous relationships between riparian communities and bison and cattle reported in the literature. East-facing slopes were selected as a reference category in relation to other cardinal directions because of perceived heat exposure. We assumed that north-facing slopes were cooler, and west- and southfacing slopes were warmer than east-facing slopes, thus influencing the selection of aspect. All variables were screened for collinearity by calculating the Pearson's correlation between variables and using $r>0.6$ as the threshold for removing a covariate (Hosmer and Lemeshow 2000). Because analysis coefficients are relative to all other model variables, 
Table 2. Chi-square comparison of bison and cattle behavior across and within species. Behavioral activities were observed from 23 May to 31 August (2010, 2011) of bison on American Prairie Reserve (APR) and Grasslands National Park (GNP) and cattle on Barnard Ranch (BR) and Weiderrick Ranch (WR). $\chi^{2}$ results represent the comparison of a specified behavior against four additional behaviors. Data were pooled across years for each site and pooled across years and sites for species.

\begin{tabular}{|c|c|c|c|c|c|c|c|c|c|}
\hline \multirow[b]{2}{*}{ Behavior } & \multicolumn{3}{|c|}{ Species comparison } & \multicolumn{3}{|c|}{ Bison location comparison } & \multicolumn{3}{|c|}{ Cattle location comparison } \\
\hline & $x^{2}$ & df & $P$ & $x^{2}$ & df & $P$ & $x^{2}$ & df & $P$ \\
\hline Grazing & 1054.02 & 1 & $<0.01$ & 5.17 & 1 & 0.02 & 11.97 & 1 & $<0.01$ \\
\hline Standing & 165.81 & 1 & $<0.01$ & 23.55 & 1 & $<0.01$ & 17.47 & 1 & $<0.01$ \\
\hline Bedded & 1068.21 & 1 & $<0.01$ & 0.06 & 1 & 0.80 & 30.87 & 1 & $<0.01$ \\
\hline Moving & 245.76 & 1 & $<0.01$ & 87.68 & 1 & $<0.01$ & 50.46 & 1 & $<0.01$ \\
\hline Other & 4.39 & 1 & 0.04 & 0.23 & 1 & 0.63 & 60.58 & 1 & $<0.01$ \\
\hline
\end{tabular}

no model selection technique was used, thus allowing a more direct comparison of covariates across location and species.

\section{RESULTS}

\section{Behavior}

Cattle and bison species differed $(P<0.01)$ in all behaviors (grazing, bedded, moving, standing, other [Table 2]) with cattle spending proportionately more time grazing and less time moving than bison (Table 3). However, the importance of landscape attributes was highlighted as both species demonstrated behavior differences across study sites. Bison behaviors differed $(P=0.02)$ between APR and GNP for grazing, standing, and moving, but not for bedded or other behaviors (Table 2). Similarly, cattle behaviors differed $(P<0.01)$ between BR and WR for all behaviors (Table 2).

Cattle spent more time at water than bison $\left(F_{1}=75.07\right.$, $P<0.01)$. Cattle on BR $(3.47 \pm 0.27 \mathrm{~min})$ and $\mathrm{WR}$ $(4.44 \pm 0.77 \mathrm{~min})$ did not differ in time spent at water $\left(F_{1}=2.29, P<0.13\right)$. However, bison on APR $(2.17 \pm 0.11$ $\mathrm{min})$ and GNP $(1.52 \pm 0.09 \mathrm{~min})$ differed in time spent at water $\left(F_{1}=19.68, P<0.01\right)$. Furthermore, the influence of temperature was dependent on the sampling location $\left(F_{5}=9.12, P<0.01\right.$ [Fig. 2]).

\section{Movement}

Cattle did not differ in MR across pasture units $(\beta=-0.17 \pm 0.27 \mathrm{SE}, P=0.206)$, thus $\mathrm{MR}$ of both cattle sites were combined. In comparison, bison moved faster than cattle

Table 3. Proportion of time of behavioral activities observed from 1 June to 31 August $(2010,2011)$ of bison on American Prairie Reserve (APR) and Grasslands National Park (GNP) and cattle on Barnard Ranch (BR) and Weiderrick Ranch (WR). Data were pooled across years.

\begin{tabular}{llllll}
\hline & \multicolumn{3}{c}{ Bison } & & \multicolumn{2}{c}{ Cattle } \\
\cline { 2 - 3 } \cline { 5 - 6 } Behavior & APR & GNP & & BR & WR \\
\hline Grazing & 0.26 & 0.28 & & 0.45 & 0.49 \\
Standing & 0.15 & 0.18 & & 0.24 & 0.20 \\
Bedded & 0.46 & 0.46 & & 0.23 & 0.29 \\
Moving & 0.11 & 0.08 & & 0.05 & 0.02 \\
Other & 0.02 & 0.02 & & 0.02 & 0.00 \\
\hline
\end{tabular}

$(\beta=0.62 \pm 0.08$ SE, $P<0.01)$. However, bison MR differed across sites $(\beta=-0.28 \pm 0.10 \mathrm{SE}, P<0.01)$, with bison on GNP moving at a $25 \%$ faster rate than bison on APR. Thus, we compared combined cattle MR to location-specific bison MR. Following our prediction, bison exhibited faster MR on APR $(\beta=0.41 \pm 0.11 \mathrm{SE}, P<0.01)$ and $\mathrm{GNP}(\beta=0.69 \pm 0.0822 \mathrm{SE}$, $P<0.01)$ than cattle. After $\beta$ transformation, this equates to bison on APR and GNP moving at a 51\% and 99\% faster rate than cattle.

Variance in FPT was maximized at $5162 \pm 13$ (patch area $=8368 \mathrm{ha}$ ) and $6100 \pm 173$ (patch area $=11690 \mathrm{ha}$ ) $\mathrm{m}$ radii for bison in APR and GNP (Fig. 3), respectively, whereas variances of cattle on $\mathrm{BR}$ and WR were maximized at $2785 \pm 103$ (area $=2435 \mathrm{ha})$ and $3040 \pm 254$ (area $=2901$ ha) $\mathrm{m}$ radii, respectively (Fig. 3). Bison in GNP also showed increased variance in FPT at $9904 \pm 374 \mathrm{~m}$ radii; however, no large-scale response was found on APR (Fig. 3). Cattle on BR demonstrated a hierarchical response at a within-pasture-unit scale of $395 \pm 53 \mathrm{~m}$ radii or 49 ha (Fig. 3). Cattle on WR also appeared to respond to resources at a fine scale $(1400 \pm 450$ $\mathrm{m}$ or $615 \mathrm{ha}$ ) in 2011; however, no response was observed in 2010.

\section{Resource Selection}

Cattle. Selection or avoidance of pasture attributes (except aspect) was similar across years and sites for cattle on BR and WR (Table 4). Cattle at both sites demonstrated strong selection for water resources and low elevations. Cattle on BR selected areas closer to roads; however, no comparison of road use by cattle on WR was possible because no major roads existed in the pasture unit. Cattle (across sites) avoided steep slopes and all vegetation types in relation to riparian communities. Cattle also demonstrated a linear response to NDVI (Fig. 4).

Bison. Resource selection by bison on APR (Table 4) was similar across years except for distance to fencing and sagebrush-steppe communities. Bison selected for sagebrushsteppe communities (relative to riparian communities) and areas farther from fencing in 2010 and avoided sagebrush-steppe communities (relative to riparian communities) and areas closer to fencing in 2011. There was no clear trend related to aspect across years. Bison selected for water sources and areas of higher elevation while avoiding roads and steeper slopes. Resource selection by bison in GNP (Table 4) within the constrained 


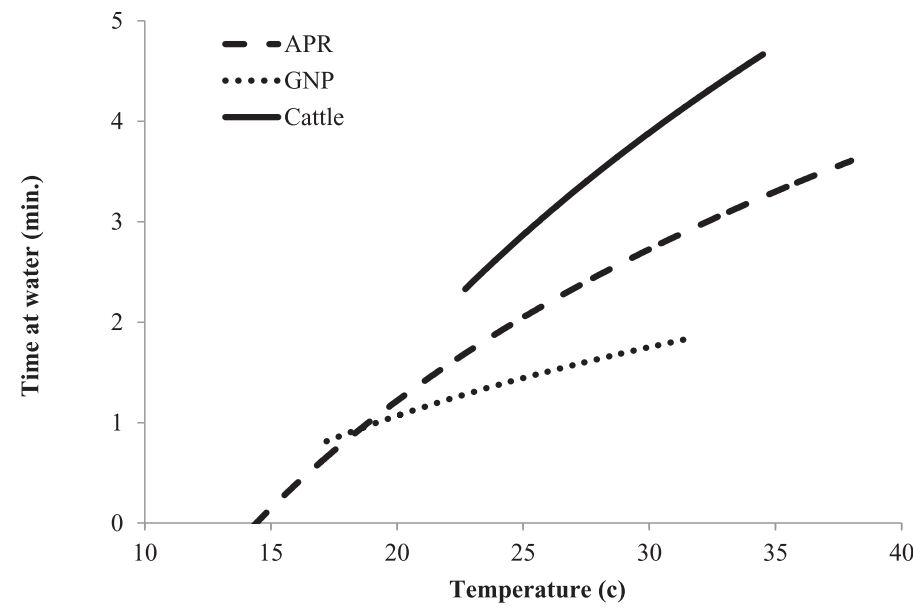

Figure 2. Influence of temperature on water use by bison on American Prairie Reserve (APR) and Grasslands National Park (GNP) and cattle on Barnard Ranch (BR) and Weiderrick Ranch (WR). Cattle did not statistically differ in time spent at water across two study locations, thus data were combined. second order (pasture unit) and third order (summer range) demonstrated similarities to APR bison for pasture attributes across time and space, particularly in selection of water sources and areas of higher elevation. Bison in GNP avoided steep slopes and most vegetation communities relative to riparian communities, including sagebrush-steppe, upland grassland, and disturbed communities across time and space.

\section{DISCUSSION}

Interest in bison and prairie conservation has been renewed with conservationists questioning the impacts of, and differences between, domestic and native grazers at a landscape scale. Bison and cattle share a common ancestry; however, evolutionary changes that have occurred over the past $600000 \mathrm{yr}$ (MacHugh et al. 1997) lead to questions of whether the two species are, or can, serve as ecological synonyms of one another. Furthermore, complications arise when addressing these questions when bison and cattle are placed under different management strategies (Fuhlendorf et al. 2010).
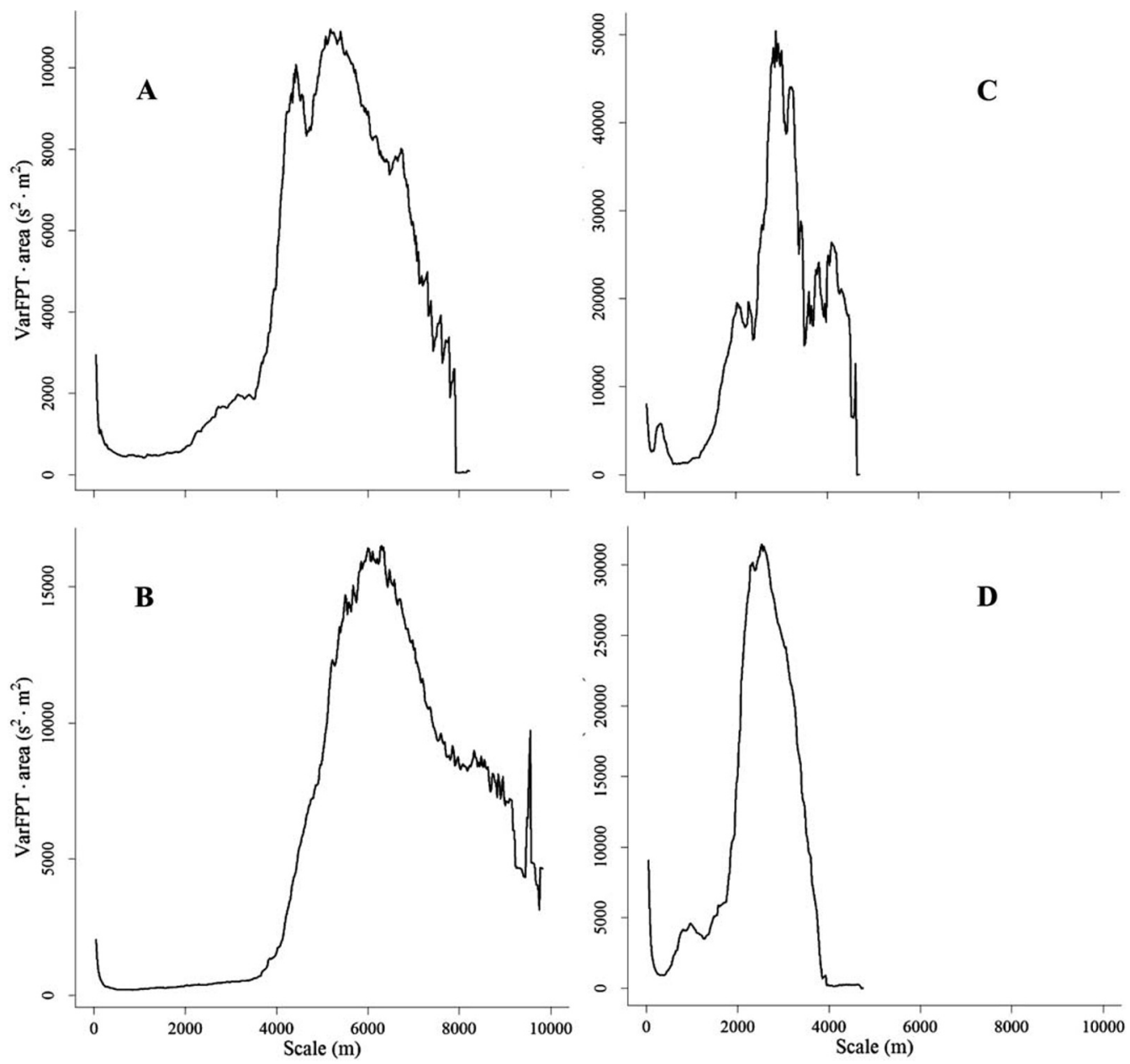

Figure 3. Examples of First Passage Time (FPT) analysis for one female bison during summer 2010 on American Prairie Reserve (A) and in Grasslands National Park (B) and for one domestic female during summer 2010 on Barnards Ranch (C) and on Weiderrick's Ranch (D). Peaks in variance of FPT (plotted up to $10000 \mathrm{~m}$ ) identify the spatial scale at which consumers perceive their resources. $X$ axis is a measure of a circle's radius. 
Table 4. Coefficient estimates from Resource Selection Functions of summer 2010 and 2011 bison use on American Prairie Reserve (APR) and Grasslands National Park (GNP). Analysis was calculated within summer range (summer) and within annual range (annual) in GNP. Coefficient values were calculated for cattle on Barnard (BR) and Weiderrick (WR) ranches. Dashes identify nonsignificant values. Variables unavailable for calculation are identified by NA. East aspect and riparian vegetation were used as reference categories. Significance at $>0.05$.

\begin{tabular}{|c|c|c|c|c|c|c|c|c|c|c|}
\hline \multirow{3}{*}{ Variables } & \multirow{2}{*}{\multicolumn{2}{|c|}{ APR (summer) }} & \multicolumn{4}{|c|}{ Bison } & \multicolumn{4}{|c|}{ Cattle } \\
\hline & & & \multicolumn{2}{|c|}{ GNP (summer) } & \multicolumn{2}{|c|}{ GNP (annual) } & \multicolumn{2}{|c|}{ BR } & \multicolumn{2}{|c|}{ WR } \\
\hline & 2010 & 2011 & 2010 & 2011 & 2010 & 2011 & 2010 & 2011 & 2010 & 2011 \\
\hline North aspect & 0.2262 & - & - & -0.1892 & -0.3833 & -0.2953 & - & -0.2435 & - & - \\
\hline South aspect & - & - & - & - & - & -0.2882 & - & 0.3922 & 0.4299 & 0.2667 \\
\hline West aspect & 0.2135 & - & - & - & - & 0.2608 & - & 0.2472 & 0.4456 & - \\
\hline Distance to fence & 0.3388 & - & -0.5995 & - & 0.1921 & -0.6575 & - & - & - & -0.3461 \\
\hline Distance to road & 0.1706 & 0.1089 & 0.1383 & 0.112 & 0.6053 & - & - & -1.6972 & NA & NA \\
\hline Distance to water & -0.4416 & -0.5284 & -0.1219 & - & -0.4284 & -0.3973 & -0.5649 & -0.4258 & -0.9565 & -1.4969 \\
\hline Elevation & 16.0968 & 11.95 & 5.4866 & 6.0146 & 18.3053 & 33.146 & - & - & 26.8354 & - \\
\hline NDVI & 25.6805 & 9.666 & -17.228 & - & 37.6806 & - & - & - & - & 17.963 \\
\hline NDVÎ2 & -32.38 & - & - & - & -43.355 & 55.0786 & - & - & - & - \\
\hline Slope & -0.1373 & -0.0617 & -0.0739 & -0.0574 & -0.0445 & - & -0.0832 & -0.1554 & -0.0728 & -0.0455 \\
\hline \multicolumn{11}{|l|}{ Vegetation } \\
\hline Disturbed & NA & - & -1.3217 & -1.2518 & -1.8345 & -1.5641 & NA & NA & NA & NA \\
\hline Eroded & 0.8378 & - & -0.3617 & -0.5754 & -1.6471 & -3.4417 & - & -0.9504 & -1.616 & 14.1033 \\
\hline Sagebrush-steppe & 0.3814 & -1.073 & - & -0.5006 & - & -1.679 & - & -0.9429 & - & -0.7111 \\
\hline Sloped grassland & - & - & -0.3539 & - & -1.679 & - & - & -1.4182 & - & -0.8715 \\
\hline Trees & NA & NA & NA & NA & - & - & -1.1957 & -1.7603 & NA & NA \\
\hline Water bodies & - & - & NA & NA & NA & NA & NA & - & - & 0.9442 \\
\hline Unclassified & - & - & 2.3274 & - & -1.1978 & -5.7184 & - & - & - & - \\
\hline Upland grassland & NA & - & - & -0.4645 & -0.2817 & - & - & - & -0.743 & -1.1259 \\
\hline Valley grassland & NA & NA & -0.3328 & - & 0.5064 & -0.4314 & NA & NA & NA & NA \\
\hline
\end{tabular}

\section{Behavior}

Historical accounts report that bison would graze for multiple days over distances of $80-160 \mathrm{~km}$ before watering, at which time they would drink heavily (Hornaday 1887a; Dary 1989). In agreement, van Vuren (1979) reported bison watering events to last 21.3 minutes in a desert landscape. However, we observed shorter watering times than those presented above. This may be due to high precipitation levels during the study, which permitted numerous short bouts of water acquisition from ephemeral water sources. The differences in water use between species, however, does provide insight into the water requirements of bison, including physiological capabilities that would permit water source removals that may lead to increased vegetation heterogeneity at a landscape scale.

Bison spent less time grazing than cattle in our study, in agreement with Plumb and Dodd (1993). However, their study reported the amount of grazing time during summer (JuneOctober) increased from $47 \%$ to $67 \%$ for bison and from $51 \%$ to $71 \%$ for cattle. The large difference in time spent grazing by bison reported in the literature and in this study $(\mathrm{APR}=26 \%$, $\mathrm{GNP}=28 \%$ ) may be a result of different observation techniques in which group behavior (previous study) or individual behavior (this study) was recorded, thus resulting in an inability to directly compare results. However, our observations of increased grazing and decreased movements by cattle, when combined with livestock stocking levels twice that of historic bison, is compatible with the hypothesis that current range practices are resulting in homogenous grazing at a landscape scale, and thus contributing to the continued decline of prairie obligate species (Knopf 1996; Fuhlendorf et al. 2006).

\section{Movement}

Bison are effectively extinct at what are thought to be ecologically relevant scales (Freese et al. 2007). However, a definition of this spatial scale for bison has, until recently, been subjective. Lott (2002) approximated an ecological functional scale for a bison herd to be as large as 1300000 ha and, Sanderson et al. (2008) stated that landscapes $>200000$ ha are exceptional contributors to the ecological recovery of bison, yet little quantitative work has demonstrated the true scale that bison require.

We identified hierarchical foraging scales for cattle, indicating use of the entire pasture with movements also organized at subpasture unit scales. These smaller scales suggest that cattle perceive and move in response to landscape patches corresponding with contemporary range management guidelines that assume distances of $1.6-3.2 \mathrm{~km}$ from water to be of moderate forage availability and further distances considered ungrazeable by cattle (Holecheck et al. 2006). Under these guidelines, the total area surrounding a singular water resource encompasses $<813.25$ ha of forage availability for cattle, lending credibility to our observations of 49 ha (BR) and 615 ha (WR) foraging patches. In comparison, bison indicated no peaks in FPT at subpasture scales. The lack of small-scale patch use by bison within APR suggests that a single bison foraging patch encompasses an area of at least the APR pasture unit (3555 ha). These results 


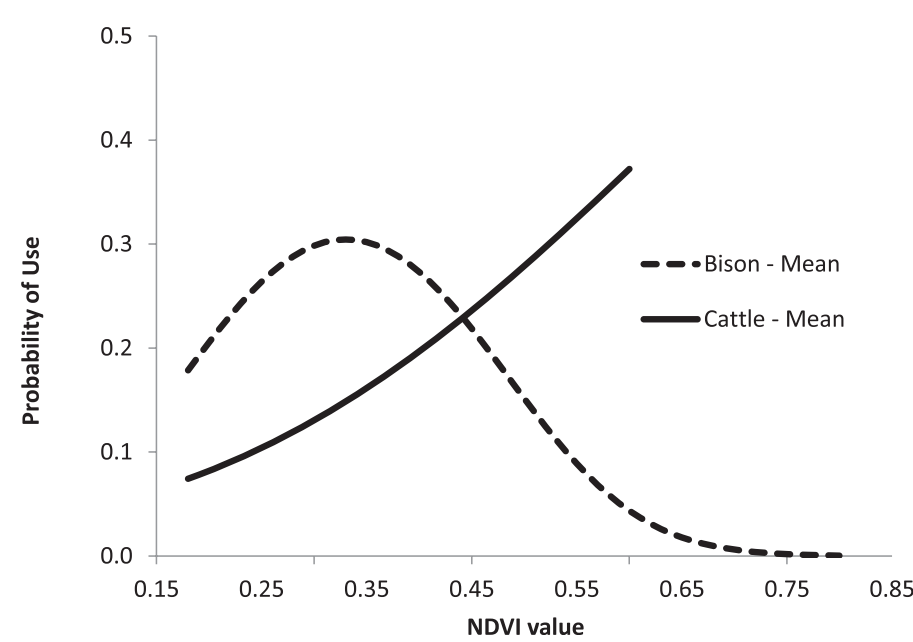

Figure 4. Averaged probability of use for intermediate green vegetation (NDVI values) for bison (at summer and annual scale) and cattle for all values (i.e., significant and nonsignificant). Selection was calculated from maximum and minimum NDVI values only and was fitted to a quadratic relationship for both species to identify whether selection was occurring for intermediate forage biomass.

are confirmed when we identified a bison summer foraging patch to be $\sim 11683.94$ ha in GNP where a larger pasture unit permits increased movement and landscape use. Furthermore, the largest scale identified in GNP may approximate a spatial scale used when historical bison populations are permitted to move freely across the landscape. Thus, we provide the first quantitative evidence within the Great Plains region that bison populations use larger spatial scales than cattle and may prefer larger landscapes than currently provided by managers and, as a result, would likely make different ecological contributions at such scales. In addition, FPT identifies a single resource patch, implying that multiple large patches are necessary, particularly when considering long temporal scales that bison may have used historically (i.e., overgrazing leading to landscape movements the following month, season, or year [Seton 1929]).

Previous studies using FPT to identify scales of movement by large herbivores have not examined the impact of a defined boundary (i.e., fencing) on detected scales (Frair et al. 2005; Williams et al. 2012). The fact that our FPT analyses identified scales of movement larger than the area of the fenced pasture is a result of using increasing radii around each GPS observation (i.e., the circles extend beyond the fence). We have interpreted these results as indicating that the individuals' movements are organized at a scale consistent with at least the entire pasture unit.

\section{Resource Selection}

Cattle located on the BR and WR demonstrated strong selection for riparian areas, lowlands, and water resources as predicted by other studies (van Vuren 1983; Allred et al. 2011). For bison, our results were similar to previous research in that bison selected for higher elevations (van Vuren 1979; Phillips 2000); however, we report avoidance of most vegetation communities by bison populations on APR and GNP in relation to riparian areas, a finding contrary to previous

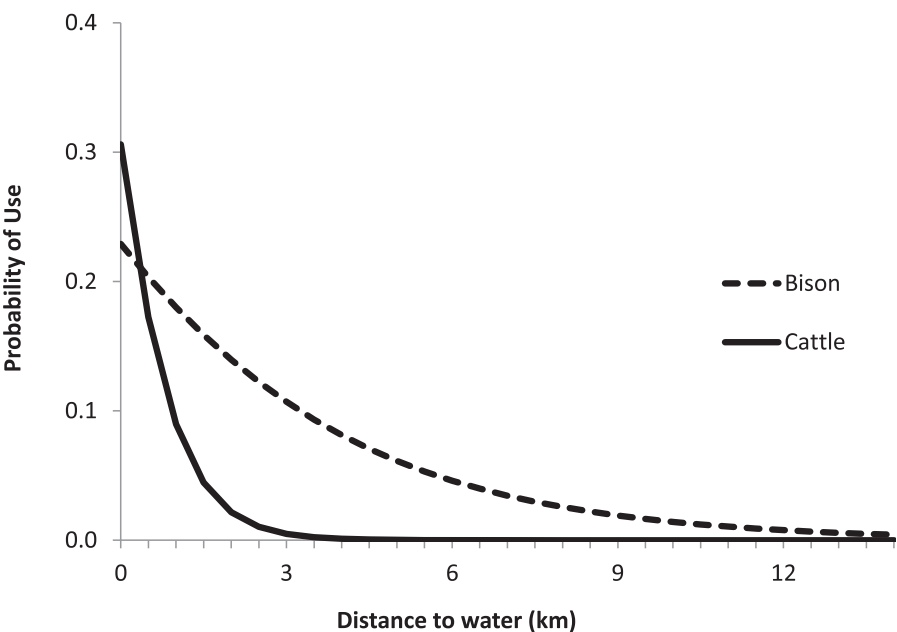

Figure 5. Probability of use for bison and cattle in relation to distance to water. Calculated using averaged values from RSF across years and locations for bison and cattle on GNP and APR.

literature. These riparian areas were generally located within steep drainage areas where water availability may have existed and may have resulted in short, opportunistic watering events when bison were nearby, thus explaining the selection of these areas.

We are the first to observe selection of water resources by bison across location and spatial scale, a finding contrary to other work throughout the literature (van Vuren 1979; Phillips 2000; Babin 2009; Allred et al. 2011). As expected, we report strong selection for water by cattle with no expected use beyond $3 \mathrm{~km}$ from water, or $\leq 707$ grazeable ha $\cdot$ water source (GH; Fig. 5). Bison selected for water, however they still used areas more than $10 \mathrm{~km}$ from water sources, a finding similar to McHugh (1958; Fig. 5). This is in contrast to other work and our expectations based on the abundance of ephemeral water but may simply be due to an inability to avoid water as a result of the significant precipitation during the study. Last, we confirmed the historic importance of summer temperatures on water requirements (Hornaday 1887a).

In terms of grazing, NDVI has been demonstrated as a viable metric for quantifying quality (i.e., standing nitrogen) and quantity (i.e., total biomass) in the study region (Thoma et al. 2002), thus allowing for the identification of tradeoffs between forage quality and quantity (Fryxell 1991). We report different selection relationships for forage quality/quantity by bison and cattle (Fig. 4). A quadratic relationship was fitted to each species to maintain consistency within the study; however, it is evident that cattle may be maximizing intake rate by selecting areas of higher forage biomass if maximum net energy intake occurs at intermediate biomass (where daily energy intake and forage biomass intersect [Hebblewhite et al. 2008; Fryxell 1991]). Previous work has varied across studies with cattle selecting for maximum intake (Distel et al. 1995), previously grazed areas (Silvia Cid and Brizuela 1998), higher forage quality (Bailey 1995), or areas of intersecting forage quantity and quality (Senft et al. 1985). Similar to other studies (Coppock et al. 1983; Coppedge and Shaw 1998; Bergman et al. 2001), bison selected for intermediate biomass (Fig. 4) except at the third order scale in 2011 on APR and GNP. We 
hypothesize these differences in 2011 are due to abundant rainfall throughout the year that may have resulted in areas of high biomass with abnormally high nutrient quality, thus relaxing the trade-off between forage quality and quantity.

\section{IMPLICATIONS}

If increased biological diversity facilitated by vegetation heterogeneity is an objective (Fuhlendorf et al. 2006) and domestic livestock are used as the dominant grazer, then the cumulative result of grazing alterations across many pasture units may reduce the impact of increased grazing periods and localized use areas by livestock, thus increasing biological diversity at a landscape scale (Fuhlendorf and Engle 2001). Potential pasture unit alterations may include changes to timing, duration, and intensity of grazing or through the use of transportable water and/or mineral sources (Ganskopp 2001; Porath et al. 2002; Bailey 2004).

If increased vegetation heterogeneity through bison grazing is an objective, then we have demonstrated that much larger pasture units may be required to facilitate bison movement, behavior, and resource use that more closely approximates historical bison populations. Although we have not quantified the pasture unit size that would permit approximations of historical use, we have provided quantitative support for the contribution of nonconstricted bison populations or populations within large pasture units to landscape vegetation heterogeneity in the Great Plains region. Due to the limited area of availability for bison in this study, we encourage similar movement analyses to be adapted to bison populations with less anthropogenic, biological, or social constrictions, thus providing additional insight into the scale of bison use across time and space. Within bison conservation areas, we have identified resources of value including variable vegetation communities that occur across upland and lowland areas. Also, we recommend testing the minimum spatial requirements of water by bison through water source reductions, thus encouraging long distance movements across the landscape that facilitate grazing heterogeneity similar to historic use (Hornaday $1887 \mathrm{~b})$.

\section{ACKNOWLEDGMENTS}

We thank the Weiderrick and Barnard ranches for providing access to their property and technicians K. Plourde, K. Gunderson, A. Derey-Wilson, and T. King. We thank B. Christensen and S. Gerrity (APR) and S. Forrest, C. Freese and M. Kauffman (WWF) for advice, review, and logistical support of this project. We appreciate the comments of two anonymous reviewers.

\section{LITERATURE CITED}

Allzed, B. W., S. D. Fuhlendorf, and R. G. Hamilton. 2011. The role of herbivores in Great Plains conservation: comparative ecology of bison and cattle. Ecosphere 2(3):article 26. doi:10.1890/ES10-00152

Altmann, J. 1974. Observational study of behavior: sampling methods. Behaviour 49:227-267.

Aune, K., And C. C. Gates. 2010. Reportable or notifiable diseases. In: C. C. Gates, C. H. Freese, P. J. P. Gogan, and M. Kotzman [EDS.]. American bison: status survey and conservation guidelines 2010. Gland, Switzerland: IUCN. p. 27- 38.
BABIN, J. 2009. Nutritional determinants of space use by bison in the Great Plains [thesis]. Quebec City, Canada: University of Laval. $44 \mathrm{p}$.

BALLEY, D. W. 1995. Daily selection of feeding areas by cattle in homogeneous and heterogeneous environments. Applied Animal Behaviour Science 45:183-200.

BALLEY, D. W. 2004. Management strategies for optimal grazing distribution and use of arid rangelands. Journal of Animal Science 82:147-153.

Bates, D., M. Maechler, and B. Bolker. 2011. Lme4: linear mixed-effects models using S4 classes. Version 0.999375-42. Available at: http://cran.r-roject.org/web/ packages/lme4/index.html. Accessed 1 November 2011.

Bennington, C. C., AND W. V. Thayne. 1994. Use and misuse of mixed-model analysis of variance in ecological studies. Ecology 75:717-722.

Bergman, C. M., J. M. Fryxell, C. C. Gates, and D. Fortin. 2001. Ungulate foraging strategies: energy maximizing or time minimizing? Journal of Animal Ecology 70:289-300.

BEYER, H. L. 2012. Geospatial modeling environment. Version 0.6.0.0. Available at: http://www.spatialecology.com/gme. Accessed 12 December 2011.

Bolker, B. M., M. E. Brooks, C. J. Clark, S. W. Geange, J. R. Poulsen, M. H. H. Stevens, AND J. S. WHITE. 2009. Generalized linear mixed models: a practical guide for ecology and evolution. Trends in Ecology and Evolution 24:127-135.

Breslow, N. E., and D. G. CLAYTon. 1993. Approximate inference in generalized linear mixed models. Journal of the American Statistical Association 88:9-25.

Calenge, C. 2006. The package adehabitat for the $r$ software: a tool for the analysis of space and habitat use by animals. Ecological Modelling 197:516-519.

Coppedge, B. R., AND J. H. Shaw. 1998. Bison grazing on seasonally burned tallgrass prairie. Journal of Range Management 51:258-264.

Coppock, D. L., J. E. Ellis, J. K. Detling, and M. I. Dyer. 1983. Plant-herbivore interactions in a North American mixed-grass prairie. II. Responses of bison to modification of vegetation by prairie dogs. Oecologia 56:10-15.

DarY, D. A. 1989. The buffalo book: the full saga of the American animal. Chicago, IL, USA: Swallow Press. 384 p.

Derner, J. D., W. K. Lauenroth, P. Stapp, and D. J. Augustine. 2009. Livestock as ecosystem engineers for grassland bird habitat in the western Great Plains of North America. Rangeland Ecology and Management 62:111-118.

Distel, R. A., E. A. LacA, T. C. Griggs, and M. W. Demment. 1995. Patch selection by cattle: maximization of intake rate in horizontally heterogeneous pastures. Applied Animal Behaviour Science 45:11-21.

Fauchald, P., And T. TveraA. 2003. Using first-passage time in the analysis of arearestricted search and habitat selection. Ecology 84:282-288.

Forrest, S. C., H. Strand, W. H. Haskins, C. Freese, J. Proctor, and E. Dinerstein. 2004. Ocean of grass: a conservation assessment for the Northern Great Plains. Bozeman, MT, USA: Northern Plains Conservation Network and Northern Great Plains Ecoregion. $191 \mathrm{p}$.

Fortin, D., J. M. Fryxell, L. O'Brodovich, and D. Frandsen. 2003. Foraging ecology of bison at the landscape and plant community levels: the applicability of energy maximization principles. Oecologia 134:219-227.

Fox, J. 2005. The $r$ commander: a basic statistics graphical user interface for $r$. Journal of Statistical Software 14:1-41.

Frair, J. L., E. H. Merrill, D. R. Visscher, D. Fortin, H. L. Beyer, and J. M. Morales. 2005. Scales of movement by elk (Cervus elaphus) in response to heterogeneity in forage resources and predation risk. Landscape Ecology 20:273-287.

Freese, C. H., K. E. Aune, D. P. Boyd, J. N. Derr, S. C. Forrest, C. C. Gates, P. J. P. Gogan, S. M. Grassel, N. D. Halbert, K. Kunkel, and K. H. Redford. 2007. Second chance for the plains bison. Biological Conservation 136:175-184.

FrYXELL, J. M. 1991. Forage quality and aggregation by large herbivores. American Naturalist 131:781-798.

Fuhlendorf, S. D., B. W. Allred, and R. G. Hamllon. 2010. Bison as keystone herbivores on the Great Plains: can cattle serve as proxy for evolutionary grazing patterns. Bronx, NY, USA: American Bison Society Working Paper No. 4. 48 p.

Funlendorf, S. D., AND D. M. Engle. 2001. Restoring heterogeneity on rangelands: ecosystem management based on evolutionary grazing patterns. BioScience $51: 625-632$.

Fuhlendorf, S. D., W. C. Harrell, D. M. Engle, R. G. Hamilton, C. A. Davis, and D. M. LESLIE, JR. 2006. Should heterogeneity be the basis for conservation? Grassland bird response to fire and grazing. Ecological Applications 16:1706-1716.

GansKOPP, D. 2001. Manipulating cattle distribution with salt and water in large aridland pastures: a GPS/GIS assessment. Applied Animal Behavior Science 73:251-262. 
Gates, C. C., C. H. Freese, P. J. P. Gogan, and M. Kotzman. 2010. American bison: status survey and conservation guidelines 2010. Gland, Switzerland: IUCN. 154 p.

Halbert, N. D., and J. N. Derr. 2007. A comprehensive evaluation of cattle introgression into US federal bison herds. Journal of Heredity 98:1-12.

Hebblewhite, M., E. Merrill, and G. McDermid. 2008. A multi-scale test of the forage maturation hypothesis in a partially migratory ungulate population. Ecological Monographs 78:141-166.

Holecheck, J. L., R. D. Pieper, and C. H. Herbel. 2006. Range management principles and practices. 6th ed. Upper Saddle River, NJ, USA: Prentice Hall. 456 p.

HornadaY, W. T. 1887a. The extermination of the American bison with a sketch of its discovery and life history. p. 418-420. Washington, DC, USA: Report of the U.S. National Museum, 1887, part 2. 548 p.

HoRnadAY, W. T. 1887b. The extermination of the American bison with a sketch of its discovery and life history. p. 377. Washington, DC, USA: Report of the U.S. National Museum, 1887, part 2. 548 p.

Hosmer, D. W., And S. LemeSHow. 2000. Applied logistic regression. 2nd ed. New York, NY, USA: John Wiley \& Sons. 392 p.

Huete, A., K. Didan, T. Miura, E. P. Rodriguez, X. Gao, and L. G. Ferreira. 2002. Overview of the radiometric and biophysical performance of the MODIS vegetation indices. Remote Sensing of Environment 83:195-213.

JoHNSON, D. H. 1980. The comparison of usage and availability measurements for evaluating resource preference. Ecology 61:65-71.

Knapp, A. K., J. M. Blair, J. M. Briggs, S. L. Collins, D. C. Hartnett, L. C. Johnson, and E. G. Towne. 1999. The keystone role of bison in North American tallgrass prairie. BioScience 49:39-50.

Knopf, F. L. 1996. Prairie legacies—birds. In: F. B. Samson and F. L. Knopf [eds.]. Prairie conservation: preserving North America's most endangered ecosystem. Washington, DC, USA: Island Press. p. 135-148.

Komers, P. E., F. Messier, AND C. C. Gates. 1992. Search or relax: the case of bachelor wood bison. Behavioral Ecology and Sociobiology 31:195-203.

LoтT, D. F. 2002. American bison: a natural history. Los Angeles, CA, USA: University of California Press. 229 p.

MacHugh, D. E., M. D. Shriver, R. T. Loftus, P. Cunningham, and D. G. Bradley. 1997. Microsatellite DNA variation and the evolution, domestication and phylogeography of Taurine and Zebu cattle (Bos Taurus and Bos indicus). Genetics 146:1071-1086

Manly, B. F. L., L. L. McDonald, D. L. Thomas, T. L. McDonald, and W. P. ERickson. 2002. Resource selection by animals: statistical design and analysis for field studies. 2nd ed. Kluwer Norwell, MA, USA: Academic Publishers. 240 p.

McHugh, T. 1958. Social behavior of the American buffalo (Bison bison bison). Zoologica 43: 1-40.

Morales, J. M., D. Fortin, J. L. Frair, and E. H. Merrill. 2005. Adaptive models for large herbivore movements in heterogeneous landscapes. Landscape Ecology 20:301-316.

Peden, D. G., G. M. Van Dyne, R. W. Rice, and R. M Hansen. 1974. The trophic ecology of Bison bison L. on shortgrass plains. Journal of Applied Ecology 11:489-497.
PHILLIPS, L. B. 2000. GIS modeling of bison habitat in southwestern Montana: a study in ranch management and conservation [thesis]. Bozeman, MT, USA: Montana State University. $87 \mathrm{p}$.

Plumb, G. E., AND J. L. Dodd. 1993. Foraging ecology of bison and cattle on a mixed prairie: implications for natural area management. Ecological Applications 3:631-643.

Porath, M. L., P. A. Momont, T. DelCurto, N. R. Rimbey, J. A. Tanaka, and M. Mclnnis. 2002. Offstream water and trace mineral salt as management strategies for improved cattle distribution. Journal of Animal Science 80:346-356.

PoweLL, F. L. A. 2006. Effects of preseribed burns and bison (Bos bison) grazing on breeding bird abundances in tallgrass prairie. The Auk 123:183-197.

Sanderson, E. W., K. H. Redford, B. Weber, K. Aune, D. Baldes, J. Berger, D. Carter, C. Curtin, J. Curtin, J. Derr, S. Dobrott, E. Fearn, C. Fleener, S. Forrest, C. Gerlach, C. C. Gates, J. E. Gross, P. Gogan, S. Grassel, J. A. Hilty, M. Jensen, K. Kunkel. D. Lammers, R. List, K. Minkowski, T. Olson, C. Pague, P. B. Robertson, and B. StePHENSON. 2008. The ecological future of the North American bison: conceiving long-term, large-scale conservation of wildlife. Conservation Biology 22:252266.

Senft, R. L., L. R. Rittenhouse, and R. G. Woodmansee. 1985. Factors influencing patterns of cattle grazing behavior on shortgrass steppe. Journal of Range Management 38:82-87.

Seton, E. T. 1929. Lives of game animals. 4 vols. Garden City, NY, USA: Doubleday, Doran \& Co. 2640 p.

Silvia Cid, M., and M. A. Brizuela. 1998. Heterogeneity in tall fescue pastures created and sustained by cattle grazing. Journal of Range Management 51:644-649.

Thoma, D. P., D. W. Balley, D. S. Long, G. A. Nielsen, M. P. Henry, M. C. Breneman, and C. Montagne. 2002. Short-term monitoring of rangeland forage conditions with AVHRR imagery. Journal of Range Management 55:383-389.

Towne, E. G., D. C. Hartnett, and R. C. Cochran. 2005. Vegetation trends in tallgrass prairie from bison and cattle grazing. Ecological Applications 15:1550-1559.

TuCKer, C. J., AND P. J. Sellers. 1986. Satellite remote sensing for primary production. International Journal of Remote Sensing 7:1395-1416.

TURCHIN, P. 1998. Quantitative analysis of movement: measuring and modeling population redistribution in animals and plants. Sunderland, MA, USA: Sinauer. $396 \mathrm{p}$.

van VuREN, D. 1979. Ecology and behavior of bison in the Henry Mountains, Utah [thesis]. Corvallis, OR, USA: Oregon State University. $47 \mathrm{p}$.

van VuREN, D. 1983. Group dynamics and summer home range of bison in southern Utah. Journal of Mammalogy 64:329-332.

Venables, W. N., and B. D. Ripley. 2002. Modern applied statistics with S. 4th ed. New York, NY, USA: Springer. $512 \mathrm{p}$.

Willams, D. M., A. C. Dechen Quinn, and W. F. Porter. 2012. Landscape effects on scales of movement by white-tailed deer in agricultural-forest matrix. Landscape Ecology 27:45-57. 